\title{
Extreme climate conditions limit seed availability to successfully attain natural regeneration of Pinus pinaster in sandy areas of Central Spain
}

\begin{tabular}{|r|l|}
\hline Journal: & Canadian Journal of Forest Research \\
\hline Manuscript ID & cjfr-2015-0257.R1 \\
\hline Manuscript Type: & Article \\
\hline Date Submitted by the Author: & $19-A u g-2015$ \\
\hline Complete List of Authors: & $\begin{array}{r}\text { RUANO, IRENE; Sustainable Forest Management Research Institute, } \\
\text { University of Valladolid \& INIA; Department of Producción Vegetal y } \\
\text { Recursos Forestales, E.T.S. de Ingenierías Agrarias, University of Valladolid } \\
\text { Manso, Rubén; INRA, UMR 1092 LERFoB; AgroParisTech, UMR 1092 } \\
\text { LERFoB } \\
\text { Fortin, Mathieu; AgroParisTech, UMR 1092 LERFoB; INRA, UMR 1092 } \\
\text { LERFoB } \\
\text { Bravo, Felipe; Sustainable Forest Management Research Institute, } \\
\text { University of Valladolid \& INIA; Department of Producción Vegetal y } \\
\text { Recursos Forestales, E.T.S. de Ingenierías Agrarias, University of Valladolid }\end{array}$ \\
\hline Keyword: & $\begin{array}{l}\text { Climate change, generalized linear mixed model, Mediterranean } \\
\text { ecosystem, natural regeneration, seed limitation }\end{array}$ \\
\hline \multicolumn{2}{|l}{} \\
\hline
\end{tabular}


1 TITLE PAGE

1. TITLE OF THE PAPER

3 Extreme climate conditions limit seed availability to successfully attain natural regeneration

4 of Pinus pinaster in sandy areas of Central Spain

5

6

2. AUTHOR NAMES AND AFFILIATIONS

7 RUANO, Irene

8 Sustainable Forest Management Research Institute, University of Valladolid \& INIA,

9 Avenida Madrid, s/n, 34004 Palencia, Spain

10 Department of Producción Vegetal y Recursos Forestales, E.T.S. de Ingenierías Agrarias,

11 University of Valladolid, Avenida Madrid, s/n, 34004 Palencia, Spain

12 E-mail: irene@pvs.uva.es

13 MANSO, Rubén

14 INRA, UMR 1092 LERFoB, 54280 Champenoux, France

15 AgroParisTech, UMR 1092 LERFoB, 54042 Nancy, France

16 E-mail : ruben.manso@nancy.inra.fr

\section{FORTIN, Mathieu}

18 AgroParisTech, UMR 1092 LERFoB, 54042 Nancy, France

19 INRA, UMR 1092 LERFoB, 54280 Champenoux, France

20 E-mail: mathieu.fortin@agroparistech.fr

21 BRAVO, Felipe 
22 Sustainable Forest Management Research Institute, University of Valladolid \& INIA, 23 Avenida Madrid, s/n, 34004 Palencia, Spain

24 Department of Producción Vegetal y Recursos Forestales, E.T.S. de Ingenierías Agrarias, 25 University of Valladolid, Avenida Madrid, s/n, 34004 Palencia, Spain

26 E-mail: fbravo@pvs.uva.es

27 3. CORRESPONDING AUTHOR

28 RUANO, Irene

29 Sustainable Forest Management Research Institute, University of Valladolid \& INIA, 30 Avenida Madrid, s/n, 34004 Palencia, Spain

31 Department of Producción Vegetal y Recursos Forestales, E.T.S. de Ingenierías Agrarias, 32 University of Valladolid, Avenida Madrid, s/n, 34004 Palencia, Spain

33 E-mail: irene@pvs.uva.es

34 Telephone: +34979108430 ; Fax: +34979108440 
35

36

37

38

39

40

41

42

43

44

45

46

47

\section{ABSTRACT}

Natural regeneration comprises different sub-processes, each of them driven by specific climatic and stand-related factors, which determine the success of natural regeneration. The objective of this study was to investigate the seed availability of maritime pine. To meet this objective seed rain was monitored for four different levels of stand density at the experimental site of Cuéllar, Spain, during a ten-year period. A generalized linear mixed model was fitted to test the effects of climatic variables and stand density on the annual seed production and seed rain. The climatic covariates were chosen among those thought to affect the key physiological phases governing these sub-processes: minimum temperature in October two years before dispersal (cone growing), April precipitation one year before dispersal (cone growing) and October-November precipitation one year before dispersal (cone maturation). No climate variable related to flowering or seed rain process was significant. Moreover, stand density was considered through a spatially explicit index called seed-source index. Primary cone growth was limited by extreme cold events. Absence of precipitation limits secondary growth while it appears to hinder final cone ripering. It turns out that seed production and seed rain may be a bottleneck for natural regeneration of Pinus pinaster under low stand densities, especially under extreme climatic scenarios.

\section{KEYWORDS}

Climate change; generalized linear mixed model; Mediterranean ecosystem; natural regeneration; seed limitation 


\section{INTRODUCTION}

56 It is well established that natural regeneration methods contribute to effectively and 57 economically perpetuate natural ecosystems in the long term (Barnes et al. 1998). As a 58 result,silviculture treatments that favour natural regeneration are one of the main issues in 59 sustainable forest management, especially in Mediterranean forests, where disturbances like

60 fire or grazing may cause erosion and extreme climatic conditions can compromise natural 61 regeneration success(Scarascia-Mugnozza et al. 2000).

62 Natural regeneration consists of different sub-processes such as seed production, seed 63 dispersal, seed storage and predation, seed germination and establishment. Multiple factors 64 can affect each one of these sub-processes, and may determine natural regeneration success.

65 Consequently, it is crucial to identify these factors and determine their influence on the entire 66 process (Price et al. 2001).

67 Seed production and dispersal are particularly relevant in natural regeneration since they 68 initiate the whole process. Seed dispersal directly depends on the amount of seeds produced, 69 the availability of appropriate dispersal agents and the maximum distance over which seeds 70 can be dispersed (Price et al. 2001). In addition, these sub-processes have been reported to 71 play a major role in seedling spatial distribution sothey are widely considered as key 72 processes to understand forest dynamics (Dovčiak et al. 2005; Nathan and Muller-Landau 73 2000).

74 Maritime pine (Pinus pinaster Ait.) is a western Mediterranean species of great economic, 75 ecological and aesthetic value. This is especially true for the Castilian Plateau in central 76 Spain, where this species covers more than 114000 ha, which represents about $7.5 \%$ of the

77 species' European distribution. In Spain, Pinus pinaster natural regeneration has been studied 78 in post-fire conditions (Calvo et al. 2007; Fernández et al. 2008; Vega et al. 2009, 2008) and 
in natural stands not affected by serious disturbances (González-Alday et al. 2008; Miguel Pérez et al. 2008; Rodríguez-García et al. 2011, 2008; Ruano et al. 2009; Del Peso et al. 2012). Studies in natural stands have focused on the Castilian Plateau's stands. Although some authors suggested that natural regeneration of Pinus pinaster was overall sufficient in this region (Miguel Pérez et al. 2008), a large array of conditions has been reported: from scarce or even null (González-Alday et al. 2009; Ruano et al. 2009) to excessive regeneration (Rodríguez-García et al. 2008). The ecological and silvicultural factors behind this variability remain unclear, their study being hindered by the lack of long-term monitoring data (Bravo et al. 2012). The knowledge of interannual Pinus pinaster seed rain pattern and the contribution of this sub-process to regeneration success or failure are particularly poor.

The study of seed dispersal in the Mediterranean basin has traditionally focused on the spatial patterns of different species: Pinus pinaster (Juez et al. 2014); Pinus pinea (Manso et al. 2012), Pinus halepensis (Nathan and Ne'eman 2004), Abies alba and Fagus sylvatica (Sagnard et al. 2007). Surprisingly, the effect of climate on seed production, which may determine seed rain temporal dynamics, has been overlooked. Currently, there is increasing agreement on the critical influence of climate on the key physiological stages of cone ripening in coniferous species, either limiting or boosting seed production (Calama et al. 2011; Keyes and Manso 2015; Mutke et al. 2005).

Although there is no evidence yet, this may also be the case for Pinus pinaster, given the twoyear cone maturation period and the harsh climatic conditions of the Castilian Plateau. More specifically, flowering occurs in spring of the first year, leaf buds emerge in April and female strobili develope in May; cone growth typically takes place after the first summer; and final cone ripening occurs by the second autumn. Seed are dispersed over spring and summer immediately after completion of ripening (Auñón and Tadesse 2000; Rodríguez Soalleiro et al. 2008). 
104 The main objective of this study was to quantify the effect of climate on the interannual

105 pattern of Pinus pinaster seed production and seed rain. To meet this objective, seed rain was

106 monitored for four different levels of stand density at the experimental site of Cuéllar, central

107 Spain, during a ten-year period. The climatic variables thought to affect the physiological

108 phases of cone ripening were tested in a generalized linear mixed-effects model. Our

109 hypotheses were that (1) the interannual seed production and seed rain pattern is climate-

110 mediated; (2) stand density has a positive effect on the overall amount of dispersed seeds; (3)

111 seed limitations can be found after clearcuttings and extreme climate conditions. We expect

112 that the findings derived from this study will contribute to our understanding of the impact of

113 climate on seed production and seed rain for different levels of density. In turn, this will help

114 define the most appropriate forest management strategy for ensuring natural regeneration in

115 this type of forest.

\section{MATERIALS AND METHODS}

119 The experiment was carried out in a natural Pinus pinaster stand at the long-term

120 experimental site of Mata de Cuéllar, Segovia, central Spain ( $41^{\circ} 22^{`} \mathrm{~N}, 4^{\circ} 29^{\prime} \mathrm{W}$, see Figure

121 1). The site is located in a flat, sandy region characterized by a semi-arid Mediterranean

122 climate, with a strong summer drought and a period of potential frost of at least three months.

123 Mean annual precipitation is $610 \mathrm{~mm}$ and mean annual temperature is $11.2{ }^{\circ} \mathrm{C}$. The floristic

124 community within the stand is composed of continental Mediterranean annual species typical

125 of central Spain, Micropyrum tenellum (L.) Link, Sedum amplexicaule DC., Vulpia myuros

126 (L.) C.C. Gmelin, Lupinus angustifolius L., with patches of shrubs, Lavandula pedunculata

127 Miller and Helichrysum italicum (Roth) G. Don, and isolated stone pine trees (Pinus pinea). 
128 Silviculture in the area is traditionally based on natural regeneration following a seed-tree 129 system adapted to resin production, leading to low stand densities.

130 The experimental site consisted of ten $70 \times 70 \mathrm{~m}$ plots that were established in 2004 for an 131 integrated analysis of maritime pine regeneration. Four treatments were tested in a split-plot 132 design: control and 3 harvest intensities (25\%, 50\% and 100\% reduction of initial basal area) 133 (Table 1), where one plot corresponded to the control and the harvest intensities were 134 replicated three times. The average basal area of the plots before harvest was $17.4 \mathrm{~m} 2 \mathrm{ha}-1$. In 135 each plot, nine seed traps $(1 \mathrm{~m} \times 1 \mathrm{~m})$ were located following a systematic design (Figure 1) in 136 order to collect dispersed seeds every month from 2004 to 2013. Seed traps are raised from 137 the ground approximately $30 \mathrm{~cm}$, the base is made by a grid to recollect the seeds and it is 138 covered by a wire mesh to avoid seed predation.

139 (Insert Table 1 and Figure 1)

\section{DATA ANALYSIS}

\subsection{Response variable}

143 In order to analyse interannual seed production and seed rain dynamics of maritime pine, we 144 selected the number of seeds collected each year in each seed trap as response variable. 145 Considering that each trap covers an area of $1 \mathrm{~m}^{2}$, the response variable is actually a seed 146 density $\left(\mathrm{seeds} / \mathrm{m}^{2}\right)$. This variable is a count and consequently we assumed it followed a 147 Poisson distribution. Therefore, a Poisson regression model based on a log link function was 148 used. Let us denote plots, traps and years with indices $i, j$ and $k$, respectively, such that $i=1$, $1492, \ldots, 10, j=1,2, \ldots, 9$ and $k=1,2,3 \ldots 10$. Then, 


$$
y_{i j k} \sim \operatorname{PoisSOn}\left(\lambda_{i j k}\right)
$$

150

$$
\lambda_{i j k}=\exp ^{\mathbf{x}_{\mathrm{ijk}} \boldsymbol{\beta}}
$$

151 where $y_{i j k}$ is the number of seeds collected in trap $j$ of plot $i$ over year $k, \lambda_{i j k}$ is the expectation

152 of the Poisson distribution, $\boldsymbol{x}_{i j k}$ is a row vector of covariates possibly affecting dispersal and $\boldsymbol{\beta}$

153 is a column vector of parameters.

\section{$154 \quad 2.2$ Explanatory variables}

155 In order to test our first hypothesis, different explanatory climate variables were evaluated to

156 represent the potential climatic drivers of seed production. Preliminary Pearson correlations

157 between a number of potential predictors and the response variable were computed. As a 158 result, 17 candidate climatic variables were selected according to the key physiological 159 processes involved in cone ripening:

160 - Flowering (two years before dispersal): total precipitation and days of precipitation in

161 April and May; maximum wind velocity in May; mean and maximum temperature in April;

162 frost days in May. Frost days are defined as those days with minimum temperature lower than $1630{ }^{\circ} \mathrm{C}$.

164 Primary growth (two years before dispersal): minimum temperature in October; frost

165 days in October; Walter's summer drought index (Walter 1973). This index is assessed as:

166 (mean daily temperatures from June to August) $-(0.333 \times$ (mean daily rainfall from June to

167 August)). Higher values indicate more intense drought. Walter's index has been used to 168 analyse the effects of summer drought on the reproduction of other Mediterranean species

169 (Espelta et al. 2011, 2008) and maritime pine seed predation (Ruano et al. 2015). 
170 - Secondary growth (one year before dispersal): total precipitation in April; frost days in

171 March and severe frost days in March. Severe frost days are defined as those days with

172 minimum temperature lower than $-5^{\circ} \mathrm{C}$.

173 - Final cone ripening (one year before dispersal): total precipitation in October and

174 November.

175 - Seed release: precipitation days in May; maximum wind velocity in summer; mean

176 temperature in August; frost days in April.

177 Climatic data were obtained from a nearby meteorological station managed by the Instituto

178 Tecnológico Agrario de Castilla y León, placed to approximately $20 \mathrm{~km}$ from the 179 experimental site (www.inforiego.org).

180 In addition to climate drivers, seed production and seed rain are likely affected by stand 181 density in the close vicinity of the traps. It can reasonably be expected that higher stand 182 density around a particular trap would lead to a greater number of seeds. A spatial explicit 183 index similar to competition index in growth modeling (Weiskittel et al. 2011) was defined to 184 account for this tree density-distance effect. For the sake of clarity, we will refer to this index 185 as the seed-source index.

186 The seed-source index was calculated for each seed trap as the sum of the inverse distances 187 between the seed trap and all potential seed sources. Trees within a $20-\mathrm{m}$ distance from each 188 seed trap were considered as seed sources. We chose this distance in the light of the estimated 189 dispersal distance of Pinus pinaster for the Castilian Plateau in the existing literature (Juez et 190 al. 2014).

192 2.3 Model fitting and evaluation 
193 The traditional Poisson regression model relies on the assumption of independence. However,

194 given the experimental design and the permanent plots, it could be reasonably expected that

195 the observations from the same trap, plot and year were not independent. The mixed-model

196 approach is one method among others that makes it possible to address this issue of dependent

197 observations through the specification of random effects. Random effects are actually error

198 terms that account for some unobserved explanatory variables at the trap, plot and year level

199 (Gregoire 1987). The mixed-model approach has been widely used in forestry (e. g. Calama

200 and Montero 2007; Collet et al. 2001; Manso et al. 2013).

201 Preliminary models were fitted for each explanatory variable to identify which one of them

202 had an influence on the response. During this step, power $\left(\mathrm{x}^{2}, \mathrm{x}+\mathrm{x}^{2}\right)$, $\log \operatorname{arithmic}(\log \mathrm{x}, \mathrm{x}+$

$203 \log \mathrm{x})$ or square $\operatorname{root}(\sqrt{\mathrm{x}}, \mathrm{x}+\sqrt{\mathrm{x}})$ transformations of the variables were tested too. In a second

204 step, the variables and transformation identified during the first step were sequentially

205 included in the model. Several covariates were rescaled to avoid numerical problems. Both

206 steps were assisted by a visual assessment of standardized residuals to make sure there were

207 no unaccounted trends left in the model. Because climatic variables are usually correlated, we

208 did not test all of them at the same time. Once the standardized residuals showed no persistent

209 trend, plot, trap and year random effects were specified on the model intercept and the

210 resulting mixed model was refitted. After several trials, only the plot and trap random effects

211 were kept. The fixed effects structure was revised when needed. Competing models were

212 compared in terms of Akaike's Information Criterion (AIC) (Akaike 1973) and statistical

213 significance was set at $\alpha=0.05$. The resulting generic model could be expressed as

214

$$
\begin{aligned}
& \lambda_{i j k}=\exp ^{\mathbf{x}_{\mathbf{i j k}} \boldsymbol{\beta}+\mathbf{u}_{\mathbf{i}}+\mathbf{u}_{\mathbf{i j}}} \\
& u_{\mathbf{i}} \sim N\left(0, \sigma_{\text {plot }}^{2}\right) \\
& u_{\mathrm{ij}} \sim N\left(0, \sigma_{\text {trap }}^{2}\right)
\end{aligned}
$$


215 where $u_{i}$ and $u_{i j}$ are two random effects common for the observations from the same plot and

216 seed trap respectively. Random effects are assumed to be independent among levels and

217 normally distributed with mean 0 and variances $\sigma_{p l o t}^{2}$ and $\sigma_{\text {trap }}^{2}$, respectively.

218 Model accuracy and unbiasedness were evaluated through the root mean squared error

219 (RMSE), mean error (E) and model efficiency (EF). Adding random effects in the model had

220 a major consequence on the predictions. The expectation of the model conditional on the

221 random effect is $E\left[y_{i j k} \mid u_{i}, u_{i j}\right]=\exp ^{\mathbf{x}_{\mathrm{ijk}} \boldsymbol{\beta}+u_{\mathrm{i}}+u_{\mathrm{ij}}}$. However, when the expectation of the model is

222 marginalized over the distribution of the random effects it results that $E\left[y_{i j k}\right] \neq \exp ^{x_{i j k} \beta}$. This

223 is due to the nonlinear form of the function and it is commonly referred to as Jensen's (1906)

224 inequality. Because we assumed that $\mathrm{u}_{\mathrm{i}}$ and $\mathrm{u}_{\mathrm{ij}}$ follow a Gaussian distribution and are

225 independent from each other, this marginalization reduces to the back-transformation of a log-

226 transformed variable (see Duan 1983): $E\left[y_{i j k}\right]=\exp ^{\mathbf{x}_{\mathrm{ijk}} \boldsymbol{\beta}+\frac{\sigma_{\text {plot }}^{2}+\sigma_{\text {trap }}^{2}}{2}}$.

227 In order to check whether the Poisson assumption held, theoretical frequencies from

228 marginalised model predictions were evaluated and compared with the observed frequencies

229 in the data as suggested in Lambert (1992) and Fortin and DeBlois (2007). All statistical

230 analyses were performed in R (R Development Core Team 2014).

\section{RESULTS}

234 The fitted model proved accurate, the bias and the root mean square error being relatively

235 small. No major departures from the assumption of Poisson distribution were found. The

236 random effects notably improved the model goodness-of-fit (AIC=9278.9 without random

237 effects; $\mathrm{AIC}=7128.3$ with random effects). The estimated variances of the plot and seed trap 
238 random effects were $\hat{\sigma}^{2}{ }_{\text {plot }}=0.0139$ and $\hat{\sigma}_{\text {trap }}=0.1248$, respectively. The best model in 239 terms of AIC was:

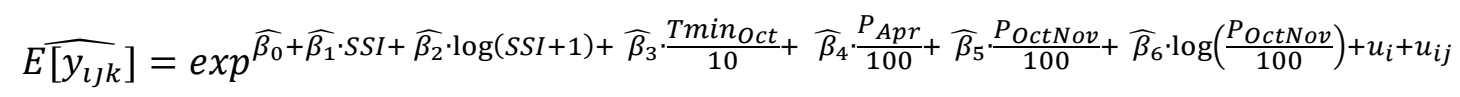

where SSI: is the seed-source index; $\operatorname{Tmin}_{O c t}$ : minimum temperature in October two years

242 before dispersal; $P_{A p r}$ : April precipitation one year before dispersal; $P_{\text {OctNov: }}$ October and

243 November precipitation one year before dispersal (Table 2). Maximum likelihood estimates

244 and their standard errors are shown in Table 3.

(Insert Table 2 and 3)

The effects of the explanatory variables on the response variable are presented in Figures 2 and 3. For each harvest intensity, predicted seed densities and their confidence intervals were generated over the observed range of each climatic variable in the study area while setting all

251 the other covariates to their mean values. As regards climate, October minimum temperatures 252 had a negative effect on predicted seed densities two years later (Figure 2a). This corresponded to the beginning of cone primary growth. In regard to secondary growth, predicted seed densities increased along with April precipitation one year before dispersal (Figure 2b). Concerning final cone ripening, an optimal value of October and November

256 precipitation (50 $\mathrm{mm}$ approximately) was found to maximize the predicted seed densities

257 (Figure 2c). This optimum occurs close to the lower limit of the recorded precipitation range 258 of October and November. Beyond this value, increasing precipitation seems to reduce seed 259 density. 
260 In the case of the seed-source index, predicted seeds and its confidence intervals were

261 produced considering the mean value of the index for each harvest intensity and the mean

262 value of the climatic variables (Figure 3). It turned out that an increase of the index induced

263 an increase of seed densities which ranged from 11 to 29 seeds $/ \mathrm{m}^{2}$. The trend appeared to be

264 slightly quadratic or asymptotic.

265 The predicted seed density for the $50 \%$-harvest intensity $\left(22 \mathrm{seeds} / \mathrm{m}^{2}\right)$ was twice that of the

266 clearcutting treatment $\left(11 \mathrm{seeds} / \mathrm{m}^{2}\right)$. Predicted seed densities in $25 \%$-harvest intensity and in

267 the control were around $30 \mathrm{seeds} / \mathrm{m}^{2}$, which was three times larger than those predicted in the

268 clearcutting treatment (Figure 3). There were no significant differences between the 25\%-

269 harvest intensity and the control (Figure 2).

270

271 (Insert Figures 2 and 3)

272

\section{DISCUSSION}

274 Very few studies have addressed the seed availability, being mainly focused on the

275 identification of spatial patterns, either as a result of a physical process (Barbeito et al. 2008;

276 Clark et al. 1999; Manso et al. 2012), a wind-mediated process (Bullock and Clarke 2000;

277 Dovčiak et al. 2005; Greene and Johnson 1989) or an animal-mediated process (Westcott et

278 al. 2005). The main constraint in the assessment of the climate effect on seed dispersal is the

279 scarcity of long-term time series that fully depict plant response to climatic conditions. With

280 few exceptions (e.g. Mutke et al. 2005, Calama et al. 2011, Keyes and Manso 2015), most

281 studies on seed dispersal are based on short-term monitoring (e.g. Hamann 2004). Here, a 10-

282 year seed rain time series has been used, a period that represents half the usual regeneration

283 period for Pinus pinaster in operational management units. The length of this time series 
284 contributes to the strength of this work. Despites this, our experimental design shows some

285 weaknesses. For instance there is only and experimental site and only one control plot.

286 Moreover plots are very close in some cases or some seed traps are too close to trees outside

287 the plots, affecting the correct identification of the seed source.

288 We can confirm our first hypothesis of a climate-mediated interannual seed production

289 pattern. Specifically all considered explanatory variables were exclusively related to cone

290 growth and maturation. Rodríguez Soalleiro et al. (2008) asserted that flowering in Pinus

291 pinaster is affected by light, temperature, precipitation and drought. We tested the effect of

292 precipitation, wind velocity or frosts as potential surrogates but none of them were found to

293 be significant in our analysis. Similarly, we did not find any association between climatic

294 variables and seed rain. Apparently, high temperatures may favour cone opening (Nathan et

295 al., 1999; Tapias et al., 2001) although this may refer serotinous species and the local

296 provenance of this study is weakly serotinous. Serotinity in Mediterranean ecosystems can be

297 a key question for seed dispersal pattern. Some Mediterranean species are adapted to fire

298 ensuring regeneration after it. This is the case of serotinous cones, which are able to hold

299 mature seeds for dispersal after fire forming a long-term canopy seed bank (Daskalakou and

300 Thanos 1996; Tapias et al. 2001). Moreover during this period, when mature seeds are in the

301 cones before seed release, predation could affect seed availability. In this case Pinus pinaster

302 can be serotinous or non-serotinous because there is a high intraspecific variability (Tapias et

303 al. 2004). Castilian Plateau provenance is considered as weakly serotinous (Tapias et al. 2004,

304 2001). In addition, no fire occurred in our experimental site, at least during the last 10 years.

305 In this respect, its serotiny is not expected to have played a significant role during the study

306 period.

307 The positive effect of precipitation during the period of secondary cone growth points out that

308 water stress is a limiting factor for seed production in Pinus pinaster in the Castilian Plateau. 
309 These findings coincide with those of Mutke et al. (2005) and Calama et al. (2011) for Pinus

310 pinea in the same area. Also, Calama et al. (2011) observed a negative effect of the number of

311 days with severe frost during the first winter after cone initiation. Interestingly, we found that

312 the higher the minimum temperature in October of the first year, the lower the predicted

313 number of seeds was.

314 Brunet et al. (2009) carried out different regionalized climate scenarios for 21 st century in

315 Spain. The different regional models used in that study agree on an increase of the minimum,

316 maximum and mean temperatures throughout the country. In contrast, predictions on

317 precipitation trends are not as consistent. Nevertheless, a slight reduction of precipitation in

318 the western half of the Iberian Peninsula and a slight increase in the eastern half is expected

319 (Brunet et al. 2009). As it applies to our case, mean temperature in autumn is expected to

320 increase between $2^{\circ} \mathrm{C}$ and $6^{\circ} \mathrm{C}$ while precipitation in spring may decrease between 20 and 50

$321 \mathrm{~mm}$. As a result of both effects, seed rain could be strongly reduced. However, this reduction

322 effect might be partly compensated for by the effect of precipitation in autumn, which is

323 expected to decrease by $40 \mathrm{~mm}$. In the light of these predictions, it is clearly necessary to

324 further analyse the effect of climate change on seed dispersal process.

325 Our findings are based on the response of seed rain to current climatic normals. For example,

326 autumn conditions are informative of Pinus pinaster seed rain because there are key

327 physiological processes that usually take place in that season. However, climatic forecasts for

328 the Mediterranean region in the next years could change the behavior of the species, bringing

329 forward or delaying processes as mega- and micro-sporangia production or cone maturation.

330 In fact, evidences of changes in species ranges has already been observed (Thuiller et al.

331 2008). In the case of coming with climate change predictions significant climatic variables

332 obtained in the present work could change because species phenology could change too, so it

333 would be necessary to review species biology. 
334 Our results also confirm our second hypothesis, since stand density is one of the main drivers

335 for seed production and seed rain. On the other hand, low stand density in a given area may

336 result in local seed limitation. For example, Lucas-Borja et al. (2012) observed an increasing

337 number of collected seeds along with stand density in a Pinus nigra forest in Central Spain.

338 On the other hand, higher stand density may lead to an overall decrease in the number of

339 dispersed seed due to competition. This is the case of Pinus pinea stands located in the

340 Castilian Plateau (Calama et al. 2011; Manso et al. 2014). Our results confirm these trends: as

341 stand density increases as measured through the seed-source index, the marginal gain in seed

342 density decreases. If a denser stand had been available in our study, a seed density decrease

343 with respect to the control plot might have been found. In any case our index, assessed

344 similarly to classic competition indexes, has worked well for predicting seed availability.

345 In the light of the aforementioned findings, a critical question remains unanswered: when

346 considering the temporal dimension, can seed production and seed rain be a bottleneck for

347 natural regeneration of Pinus pinaster in the Castilian Plateau? According to Matney and

348 Hodges (1991) a recruit density of 2000 seedlings/ha is the minimum requirement for

349 successful natural regeneration However, a density of between 1000 and 1500 viable trees/ha

350 may be considered satisfactory in stands with abiotic stress (Rodríguez-García et al. 2010).

351 Several factors can negatively affect the subsequent stages of the regeneration process after

352 dispersal, namely predation of the dispersed seeds and the limiting climatic conditions

353 occurring in the Mediterranean ecosystems during the initial months of seedling establishment

354 (Miguel Pérez et al. 2008). The impact of predation, germination failure and seedling survival

355 in the specific case of Pinus pinaster can be analysed taking other experiments carried out in

356 the same experimental site into account: Ruano et al. (2015) studied the effect of predation on

357 belowground seed bank. They observed mean percentages of seed predation around $75 \%$ for

358 control and clear cutting plots, around $86 \%$ for $25 \%$ harvest intensity plots and around $92 \%$ 
359 for 50\% harvest intensity plots. Moreover, Ruano et al. (2009) analysed the effect of harvest

360 intensity and summer water regimes on germination and seedling survival during 18 months.

361 They observed percentages of germination around $40 \%$ for clearcut, control and $50 \%$ harvest

362 intensity plot and around $60 \%$ for $25 \%$ harvest intensity plot. Furthermore, they found

363 percentages of seedling survival around $13 \%$ for clear cut plot, around $25 \%$ for control and

$36450 \%$ harvest intensity plots and around $45 \%$ for $25 \%$ harvest intensity plot.

365 Taking into account these percentages, it is possible to obtain a rough estimate of the required

366 seed rain to reach the threshold of 2000 seedlings/ha for successful establishment. Seed

367 densities of around $5 \mathrm{seeds} / \mathrm{m}^{2}$ for $25 \%$ harvest intensity plots, around $9 \mathrm{seeds} / \mathrm{m}^{2}$ for control

368 plots, around 18 seeds $/ \mathrm{m}^{2}$ for clearcut plots and around 25 seeds $/ \mathrm{m}^{2}$ for $50 \%$ harvest intensity

369 plots would be necessary to ensure a successful regeneration. According to our results, current

370 seed rain could be enough in the control and $25 \%$ harvest intensity, even if less favourable

371 climatic conditions occurred. However, natural regeneration may fail in the other cases. Mean

372 predicted seed rain in $50 \%$ harvest intensity plots was around $23 \mathrm{seeds} / \mathrm{m}^{2}$, becoming

373 progressively lower under more extreme climatic events. When clearcutting is carried out,

374 seed rain does not seem abundant enough regardless of the climatic conditions. In this case,

375 the estimated density of established recruits is lower than 1200 seedlings/ha for a seed rain

376 density of 10 seeds $/ \mathrm{m}^{2}$.

377 In terms of forest management, the present study can support decision making related to

378 Pinus pinaster natural regeneration. Whether seed production and seed rain is a bottleneck for

379 natural regeneration is clearly related to harvest intensities, which validates our third

380 hypothesis. Because interannual pattern of seed production is climate dependent, good

381 conditions may eventually compensate for harvest intensities while harsh conditions will

382 inevitably lead to regeneration failure. This is the case of the $50 \%$-harvesting operation, 
383 which is a widely-applied silvicultural practice in the study area. Therefore forest

384 management should reduce harvest intensities in this area to assure natural regeneration.

385 Our knowledge on the impact of climate may help anticipate restoration treatments in order to 386 alleviate these constraints. For example, a positive effect of scarification on seedling 387 emergence has been reported for temperate and continental pine forests (Boucher et al. 2007; 388 Karlsson and Nilsson 2005; Nilsson et al. 2006) and in the Mediterranean area (Prévosto and 389 Ripert 2008). In fact, scarification is usually recommended in the event of insufficient natural 390 regeneration in Pinus pinaster stands (Rodríguez Soalleiro et al. 2008). Given that seed 391 dispersal takes place in summer and that our model can predict seed rain several months in 392 advance, scarification can be prescribed during the winter prior to dispersal if need be. This 393 way, it could be possible to improve the seedling emergence after a year of higher seed rain 394 carrying out a soil scarification the previous winter.

395 The main interest of this work was to analyse the impact of climatic factors on the between396 years pattern of seed production and seed rain. Although the spatial dimension has been taken 397 into account, our approach presents some limitations in this respect. Commonly, tree-related 398 variables such as diameter at breast height, crown size or height are used as a proxy of 399 individual tree fecundity (de-Lucas et al. 2008; González-Martínez et al. 2006). 400 Unfortunately, we could not consider any of these variables when assessing our seed-source 401 index because we did not have enough measurements. Nevertheless, the proposed index 402 provides, at least, consistent and unbiased inference on the effect of local stand density on 403 seed rain.

404 Pinus pinaster plantations were established in the southern hemisphere (mainly in South 405 Africa and Australia) where it can escape from plantations and spread into native ecosystems 406 (Rouget et al., 2004). It is for this reason that Pinus pinaster has been considered one of the 407 world's worst invasive tree species (Lowe et al. 2004). It would be necessary to repeat this 
408 type of experiments to generalize our results outside or even inside its natural range due to

409 Pinus pinaster high variability in terms of ecotypes, plasticity and habitat conditions.

\section{CONSEQUENCES FOR MANAGEMENT}

411 In the present study, we have analyzed the effect of climate on the interannual pattern of

412 Pinus pinaster seed production and seed rain in the Castilian Plateau. The impact of climate

413 over the entire seed production process has been studied, from flowering to seed release.

414 Temperature seems to control primary cone growth, while absence of precipitation limits

415 secondary growth. Contrastingly, precipitation appears to hinder final cone ripening.

416 Interestingly, any climatic variable was apparently related to flowering or seed rain process.

417 Currently seed production and seed rain seem to be a bottleneck for natural regeneration of

418 Pinus pinaster under intensive harvest intensities. Our results suggest that seed-limitation

419 problems may arise with the 50\% harvest intensity under extreme climatic scenarios, 420 specifically with lower precipitation during spring and autumn. Moreover seed rain may not 421 be enough to obtain a successful regeneration when clearcuttings are conducted. Therefore 422 harvest intensity recommendations need to be revised, or at least, a homogeneous spatial 423 distribution of the trees should be promoted.

424 In addition, it could be possible to improve natural regeneration success carrying out 425 silvicultural treatments. According our results scarification could be applied to take advantage 426 of summers with higher seed rain.

\section{ACKNOWLEDGEMENTS}

This contribution has been supported by the Project AGL2011-29701-C02-02 of Spanish

430 Ministry of Economy and Competitiveness. I. Ruano acknowledges the FPU scholarship 431 program from the Spanish Ministry of Education. The UMR 1092 LERFoB is supported by a 
432 grant overseen by the French National Research Agency (ANR) as part of the

433 “Investissements d'Avenir” program (ANR-11-LABX-0002-01, Lab of Excellence

434 ARBRE). The authors also thank Inforiego (www.inforiego.org) of Instituto Tecnológico

435 Agrario de Castilla y León for climatic data.

\section{REFERENCES}

Akaike, H. 1973. Information theory and an extension of the maximum likelihood principle. In 2nd International Symposium on Information Theory. Edited by Csáki F. Akadémiai Kiadó, Budapest, pp 267-281.

Auñón, F. J., Tadesse, W. 2000. Crecimiento del brote y floración femenina de Pinus pinaster Ait. en el banco clonal situado en Carbonero El Mayor (Segovia). Foresta 9, 30-34.

Barbeito, I., Pardos, M., Calama, R., Canellas, I. 2008. Effect of stand structure on Stone pine (Pinus pinea L.) regeneration dynamics. Forestry 81, 617-629. doi:10.1093/forestry/cpn037

Barnes, B.V., Zak, D., Denton, S.R., Spurr, S.H. 1998. Regeneration ecology. In Forest Ecology. John Wiley \& Sons, Inc., New York, USA pp. 94-121

Boucher, J.-F., Bernier, P.Y., Margolis, H.A., Munson, A.D. 2007. Growth and physiological response of eastern white pine seedlings to partial cutting and site preparation. For. Ecol. Manage. 240, 151-164. doi:10.1016/j.foreco.2006.12.020

Bravo, F., Álvarez González, J.G., Del Rio, M., Barrio-Anta, M., Bonet, J.A., Bravo-Oviedo, A., Calama, R., Castedo-Dorado, F., Crecente-Campo, F., Condés, S., Diéguez-Aranda, U., González-Martínez, S.C., Lizarralde, I., Nanos, N., Madrigal, A., Martínez-Millán, F.J., Montero, G., Ordóñez, C., Palahi, M., Piqué, M., Rodríguez, F., Rodríguez-Soalleiro, R., Rojo, A., Ruiz-Peinado, R., Sánchez-González, M., Trasobares, A., Vázquez-Piqué, J. 2012. Growth and yield models in Spain: historical overview, contemporary examples and perspectives. Instituto Universitario de Investigación en Gestión Forestal Sostenible (Universidad de Valladolid-INIA) y Unidad de Gestió Forestal Sostenible (Universidad de Santiago de Compostela), Spain

Brunet, M., Casado, M.J., Castro, M. De, Galán, P., López, J.A., Martin, J.M., Pastor, A., Petisco, E., Ramos, P., Ribalaygua, J., Rodriguez, E., Sanz, I., Torres, L. 2009. Generación de escenarios regionalizados de cambio climático para España.

Bullock, J.M., Clarke, R.T. 2000. Long distance seed dispersal by wind: measuring and modelling the tail of the curve. Oecologia 124, 506-521. doi:10.1007/PL00008876 
Calama, R., Montero, G. 2007. Cone and seed production from stone pine (Pinus pinea L.) stands in Central Range (Spain). Eur. J. For. Res. 126, 23-35. doi:10.1007/s10342-005-01008

Calama, R., Mutke, S., Tomé, J., Gordo, J., Montero, G., Tomé, M. 2011. Modelling spatial and temporal variability in a zero-inflated variable: The case of stone pine (Pinus pinea L.) cone production. Ecol. Modell. 222, 606-618. doi:10.1016/j.ecolmodel.2010.09.020

Calvo, L., Santalla, S., Valbuena, L., Marcos, E., Tárrega, R., Luis-Calabuig, E. 2007. Postfire natural regeneration of a Pinus pinaster forest in NW Spain. Plant Ecol. 197, 81-90. doi:10.1007/s11258-007-9362-1

Clark, J.S., Silman, M., Kern, R., Macklin, E., HilleRisLambers, J. 1999. Seed dispersal near and far: patterns across temperate and tropical forest. Ecology 80, 1475-1494. doi:10.1890/0012-9658(1999)080[1475:SDNAFP]2.0.CO;2

Collet, C., Lanter, O., Pardos, M. 2001. Effects of canopy opening on height and diameter growth in naturally regenerated beech seedlings. Ann. For. Sci. 58, 127-134. doi:10.1051/forest:2001112

Daskalakou, E., Thanos, C. 1996. Aleppo Pine ( Pinus Halepensis ) Postfire Regeneration: the Role of Canopy and Soil Seed Banks. Int. J. Wildl. Fire 6, 59. doi:10.1071/WF9960059

de-Lucas, A.I., Robledo-Arnuncio, J.J., Hidalgo, E., González-Martínez, S.C. 2008. Mating system and pollen gene flow in Mediterranean maritime pine. Heredity (Edinb). 100, 390-9. doi:10.1038/sj.hdy.6801090

Del Peso, C., Bravo, F., Ruano, I., Pando, V. 2012. Patrones de diseminación y nascencia de Pinus pinaster Ait. en Meseta Castellana. In La regeneración natural de los pinares en los arenales de la meseta castellana. Edited by Gordo, F.J., Calama, R., Pardos, M., Bravo, F., Montero, G. Instituto Universitario de Investigación en Gestión Forestal Sostenible (Universidad de Valladolid-INIA), Valladolid, Spain, pp 161-174

Dovčiak, M., Frelich, L.E., Reich, P.B. 2005. Pathways in old-field succession to white pine: seed rain, shade, and climate effects. Ecol. Monogr. 75, 363-378. doi:10.1890/03-0802

Duan, N. 1983. Smearing Estimate: A Nonparametric Retransformation Method. J. Am. Stat. Assoc. 78 (383): 605-610

Espelta, J.M., Arnan, X., Rodrigo, A. 2011. Non-fire induced seed release ina weakly serotinous pine: climatic factors, maintenance costs or both? Oikos 120, 1752-1760. doi:10.1111/j.1600-0706.2011.19570.x

Espelta, J.M., Cortés, P., Molowny-Horas, R., Sánchez-Humanes, B., Retana, J. 2008. Masting mediated by summer drought reduces acorn predation in mediterranean oak forests. Ecology 89, 805-817. doi:10.1890/07-0217.1

Fernández, C., Vega, J.A., Fonturbel, T., Jiménez, E., Pérez-Gorostiaga, P., 2008. Effects of wildfire, salvage logging and slash manipulation on Pinus pinaster Ait. recruitment in Orense (NW Spain). For. Ecol. Manage. 255, 1294-1304. doi:10.1016/j.foreco.2007.10.034Fortin, 
M., DeBlois, J. 2007. Modeling Tree Recruitment with Zero-Inflated Models: The Example of Hardwood Stands in Southern Québec, Canada. For. Sci. 53 (4) 529-539.

González-Alday, J., Martínez-Ruiz, C., Bravo, F. 2009. Evaluating different harvest intensities over understory plant diversity and pine seedlings, in a Pinus pinaster Ait. natural stand of Spain. Plant Ecol. 201, 211-220. doi:10.1007/s11258-008-9490-2

González-Martínez, S.C., Burczyk, J., Nathan, R., Nanos, N., Gil, L., Alía, R. 2006. Effective gene dispersal and female reproductive success in Mediterranean maritime pine (Pinus pinaster Aiton). Mol. Ecol. 15, 4577-4588. doi:10.1111/j.1365-294X.2006.03118.x

Greene, D.F., Johnson, E.A. 1989. A model of wind dispersal of winged or plumed seeds. Ecology 70 (2), 339-347.

Gregoire, T.G. 1987. Generalized error structure for forestry yield models. For. Sci. 33: 423444.

Hamann, A. 2004. Flowering and fruiting phenology of a Philippine submontane rain forest: climatic factors as proximate and ultimate causes. J. Ecol. 92, 24-31. doi:10.1111/j.13652745.2004.00845.x

Jensen, J.L.W.V. 1906. Sur les fonctions convexes et les inégalités entre les valeurs moyennes. Acta Math. 30, 175-193

Juez, L., González-Martínez, S.C., Nanos, N., de-Lucas, A.I., Ordóñez, C., del Peso, C., Bravo, F. 2014. Can seed production and restricted dispersal limit recruitment in Pinus pinaster Aiton from the Spanish Northern Plateau? For. Ecol. Manage. 313, 329-339. doi:10.1016/j.foreco.2013.10.033

Karlsson, M., Nilsson, U. 2005. The effects of scarification and shelterwood treatments on naturally regenerated seedlings in southern Sweden. For. Ecol. Manage. 205, 183-197. doi:10.1016/j.foreco.2004.10.046

Keyes, C.R., Manso, R. 2015. Climate-influenced ponderosa pine (Pinus ponderosa) seed masting trends in western Montana, USA. For. Syst. 24(1) 1-7 doi:10.5424/fs/2015241-05606

Lambert D. 1992. Zero-inflated Poisson regression, with an application to defects in manufacturing. Technometrics 34, 1-14

Lowe S., Browne M., Boudjelas S., De Pooter M. 2004. 100 de las Especies Exóticas Invasoras más dañinas del mundo. The invasive Species Specialist Group (ISSG) a specialist group of the Species Survival Commission (SSC) of the World Conservation Union (IUCN)

Lucas-Borja, M.E., Fonseca, T.F., Lousada, J.L., Silva-Santos, P., Garcia, E.M., Abellán, M.A. 2012. Natural regeneration of Spanish black pine [Pinus nigra Arn. ssp. salzmannii (Dunal) Franco] at contrasting altitudes in a Mediterranean mountain area. Ecol. Res. 27, 913-921. doi:10.1007/s11284-012-0969-x 
Manso, R., Fortin, M., Calama, R., Pardos, M. 2013. Modelling seed germination in forest tree species through survival analysis. The Pinus pinea L. case study. For. Ecol. Manage. 289, 515-524. doi:10.1016/j.foreco.2012.10.028

Manso, R., Pardos, M., Keyes, C.R., Calama, R. 2012. Modelling the spatio-temporal pattern of primary dispersal in stone pine (Pinus pinea L.) stands in the Northern Plateau (Spain). Ecol. Modell. 226, 11-21. doi:10.1016/j.ecolmodel.2011.11.028

Manso, R., Pukkala, T., Pardos, M., Miina, J., Calama, R. 2014. Modelling Pinus pinea forest management to attain natural regeneration under present and future climatic scenarios. Can. J. For. Res. 44, 250-262. doi:10.1139/cjfr-2013-0179

Matney, D.T., Hodges, D.J. 1991. Evaluating regeneration success. In Forest Regeneration Manual. Edited by M.L. Duryea and P.M. Dougherty. Kluwer Academic, Don- drecht, The Netherlands pp. 321-331

Miguel Pérez, I., González-Martínez, S.C., Alía Miranda, R., Gil Sánchez, L. 2008. Growth phenology and mating system of maritime pine (Pinus pinaster Aiton) in central Spain. For. Syst. 11, 193-204. doi:10.5424/768

Mutke, S., Gordo, J., Gil, L. 2005. Variability of Mediterranean Stone pine cone production: Yield loss as response to climate change. Agric. For. Meteorol. 132, 263-272. doi:10.1016/j.agrformet.2005.08.002

Nathan, R., Muller-Landau, H.C. 2000. Spatial patterns of seed dispersal, their determinants and consequences for recruitment. Trends Ecol. Evol. 15, 278-285. doi:10.1016/S01695347(00)01874-7

Nathan, R., Ne'eman, G. 2004. Spatiotemporal dynamics of recruitment in Aleppo pine (Pinus halepensis Miller). Plant Ecol. 171, 123-137. doi:10.1023/B:VEGE.0000029379.32705.0f

Nathan, R., Safriel, U.N., Noy-Meir, I., Schiller, G., 1999. Seed release without fire in Pinus halepensis, a Mediterranean serotinous wind-dispersed tree. J. Ecol. 87, 659-669. doi:10.1046/j.1365-2745.1999.00382.x

Nilsson, U., Örlander, G., Karlsson, M. 2006. Establishing mixed forests in Sweden by combining planting and natural regeneration-Effects of shelterwoods and scarification. For. Ecol. Manage. 237, 301-311. doi:10.1016/j.foreco.2006.09.053

Prévosto, B., Ripert, C. 2008. Regeneration of Pinus halepensis stands after partial cutting in southern France: Impacts of different ground vegetation, soil and logging slash treatments. For. Ecol. Manage. 256, 2058-2064. doi:10.1016/j.foreco.2008.07.027

Price, D.T., Zimmermann, N.E., Meer, P.J. van der, Lexer, M.J., Leadley, P., Jorritsma, I.T.M., Schaber, J., Clark, D.F., Lasch, P., McNulty, S., Wu, J., Smith, B. 2001. Regeneration in Gap Models: Priority Issues for Studying Forest Responses to Climate Change. Clim. Change 51, 475-508. doi:10.1023/A:1012579107129 
R Development Core Team 2014. R: A language and environment for statistical computing. R Foundation for Statistical Computing, Vienna, Austria. URL: http://www.R-project.org

Rodríguez-García, E., Bravo, F., Spies, T.A. 2011. Effects of overstorey canopy, plant-plant interactions and soil properties on Mediterranean maritime pine seedling dynamics. For. Ecol. Manage. 262, 244-251. doi:10.1016/j.foreco.2011.03.029

Rodríguez-García, E., Juez, L., Bravo, F. 2010. Environmental influences on post-harvest natural regeneration of Pinus pinaster Ait. in Mediterranean forest stands submitted to the seed-tree selection method. Eur. J. For. Res. 129, 1119-1128. doi:10.1007/s10342-010-03997

Rodríguez-García, E., Juez, L., Guerra, B., Bravo, F. 2008. Análisis de la regeneración natural de Pinus pinaster Ait. en los arenales de Almazán-Bayubas (Soria, España). For. Syst., 25-38.

Rodríguez-Soalleiro, R., Serrada Hierro, R., Lucas Santolaya, J.A., Alejano Monte, R., Del Río Gaztelurrutia, M., Torres Álvarez, E., Cantero Amiano, A. 2008. Selvicultura de Pinus pinaster Ait. subsp. atlantica. In Compendio de selvicultura aplicada en España. Edited by R. Serrada, G. Montero, J.A. Reque. INIA, Spain, pp 367-398

Rouget, M., Richardson, D.M., Milton, S.J., Polakow, D. 2004. Predicting invasion dynamics of four alien Pinus species in a highly fragmented semi-arid shrubland in South Africa. Plant Ecol. 152, 79-92. doi:10.1023/A:1011412427075

Ruano, I., del Peso, C., Bravo, F. 2015. Post-dispersal predation of Pinus pinaster Aiton seeds: key factors and effects on belowground seed bank. Eur. J. For. Res. 134, 309-318. doi:10.1007/s 10342-014-0853-z

Ruano, I., Pando, V., Bravo, F. 2009. How do light and water influence Pinus pinaster Ait. germination and early seedling development? For. Ecol. Manage. 258, 2647-2653. doi:10.1016/j.foreco.2009.09.027

Sagnard, F., Pichot, C., Dreyfus, P., Jordano, P., Fady, B. 2007. Modelling seed dispersal to predict seedling recruitment: Recolonization dynamics in a plantation forest. Ecol. Modell. 203, 464-474. doi:10.1016/j.ecolmodel.2006.12.008

Scarascia-Mugnozza, G., Oswald, H., Piussi, P., Radoglou, K. 2000. Forests of the Mediterranean region: gaps in knowledge and research needs. For. Ecol. Manage. 132, 97109. doi:10.1016/S0378-1127(00)00383-2

Tapias, R., Climent, J., Pardos, J.A., Gil, L. 2004. Life histories of Mediterranean pines. Plant Ecol. 171, 53-68. doi:10.1023/B:VEGE.0000029383.72609.f0

Tapias, R., Gil, L., Fuentes-utrilla, P., Pardos, J.A. 2001. Canopy seed banks in Mediterranean pines of south- eastern Spain: a comparison between Pinus halepensis Mill ., P . pinaster Ait ., P . nigra Arn . and P . pinea L . J. Ecol. 89, 629-638.

Thuiller, W., Albert, C., Araújo, M.B., Berry, P.M., Cabeza, M., Guisan, A., Hickler, T., Midgley, G.F., Paterson, J., Schurr, F.M., Sykes, M.T., Zimmermann, N.E. 2008. Predicting 
global change impacts on plant species' distributions: Future challenges. Perspect. Plant Ecol. Evol. Syst. 9, 137-152. doi:10.1016/j.ppees.2007.09.004

Vega, J.A., Fernández, C., Pérez-Gorostiaga, P., Fonturbel, T., 2008. The influence of fire severity, serotiny, and post-fire management on Pinus pinaster Ait. recruitment in three burnt areas in Galicia (NW Spain). For. Ecol. Manage. 256, 1596-1603. doi:10.1016/j.foreco.2008.07.005

Vega, J.A., Fernández, C., Pérez-Gorostiaga, P., Fonturbel, T. 2009. Response of maritime pine (Pinus pinaster Ait.) recruitment to fire severity and post-fire management in a coastal burned area in Galicia (NW Spain). Plant Ecol. 206, 297-308. doi:10.1007/s11258-009-9643$\mathrm{y}$

Weiskittel, A.R., Hann, D.W., Kershaw, J.A., Jr., Vanclay, J. K. 2011. Forest Growth and Yield Modeling. John Wiley \& Sons. Hoboken, New Jersey, USA

Westcott, D.A., Bentrupperbäumer, J., Bradford, M.G., McKeown, A. 2005. Incorporating patterns of disperser behaviour into models of seed dispersal and its effects on estimated dispersal curves. Oecologia 146, 57-67. doi:10.1007/s00442-005-0178-1

\section{TABLES}

Table 1. BA: Basal area $\left(\mathrm{m}^{2} / \mathrm{ha}\right)$ and $\mathrm{N}$ : stand density (trees/ha) before and after harvest in the experimental site plots

\begin{tabular}{cccccc}
\hline Plot & $\begin{array}{c}\text { harvest } \\
\text { intensity }\end{array}$ & BA before harvest & BA after harvest & N before harvest & N after harvest \\
\hline 1 & $100 \%$ & 16.64 & 0.00 & 136.73 & 0.00 \\
2 & $25 \%$ & 17.66 & 13.25 & 140.82 & 79.59 \\
3 & $100 \%$ & 17.89 & 0.00 & 126.53 & 0.00 \\
4 & $25 \%$ & 18.03 & 13.68 & 161.22 & 95.92 \\
5 & $25 \%$ & 21.35 & 16.06 & 173.47 & 124.49 \\
6 & $50 \%$ & 20.85 & 10.24 & 187.76 & 83.67 \\
7 & $50 \%$ & 14.06 & 7.01 & 114.29 & 44.90 \\
8 & $50 \%$ & 15.07 & 7.96 & 130.61 & 63.27
\end{tabular}


$9 \quad 100 \%$

18.91

0.00

153.06

0.00

10

$0 \%$

13.46

13.46

95.92

95.92

Table 2. Characteristics of the significant variables: sampling size (n), mean, maximum, minimum and standard deviation.

\begin{tabular}{lccccc}
\hline & $\mathrm{n}$ & Mean & Maximum & Minimum & Standard deviation \\
\hline Seeds & 900 & 16 & 114 & 0 & 15.269 \\
& & & & & 0.583 \\
Seed-source index (SSI) & 90 & 0.823 & 2.789 & 0.000 & 1.552 \\
Tmin $_{\text {Oct }}$ (primary growth) & 10 & 5.517 & 7.970 & 3.610 & 17.323 \\
$\mathrm{P}_{\text {Apr }}$ (secondary growth) & 10 & 46.10 & 82.63 & 20.40 & 68.004 \\
$\mathrm{P}_{\text {OctNov }}$ (final ripering) & 10 & 110.30 & 260.60 & 13.59 & \\
\hline
\end{tabular}

Table 3. Fitted fixed effects. Estimated parameters, standard error and P-value. AIC (Akaike's Information Criterion): 7128.3; BIC (Bayesian Information Criterion): 7171.5; log-likelihood: $-3555.1$.

\begin{tabular}{lcccc}
\hline Effect & Parameter & Estimate & Standard Error & P-value \\
\hline Intercept & $\beta_{0}$ & 2.591 & 0.138 & $<2 * 10^{-16}$ \\
SSI & $\beta_{1}$ & -1.612 & 0.384 & $2.67 * 10^{-5}$ \\
$\log (\mathrm{SSI}+1)$ & $\beta_{2}$ & 4.305 & 0.730 & $3.64 * 10^{-9}$ \\
Tmin & & & & \\
$\mathrm{P}_{\text {Opt }}$ (primary growth) & $\beta_{3}$ & -0.421 & 0.070 & $<2 * 10^{-16}$ \\
& $\beta_{4}$ & 0.692 & 0.046 & $<2 * 10^{-16}$
\end{tabular}




\begin{tabular}{lcccc}
$\mathrm{P}_{\text {OctNov }}($ final ripering) & $\beta_{5}$ & -0.833 & 0.036 & $2.5 * 10^{-9}$ \\
$\log \left(\mathrm{P}_{\text {OctNov }}\right)$ (final ripering) & $\beta_{6}$ & 0.405 & 0.024 & $<2 * 10^{-16}$ \\
\hline
\end{tabular}




\section{FIGURE CAPTATIONS}

Figure 1. Location of the experimental design with a climodiagram. Position of all the trees and stumps of the experimental site and position of the seed traps and nursery trays to control predation. Harvest intensity is indicated near each plot. Climodiagram from Rivas-Martínez and Rivas-Sáenz (1996-2009)

Figure 2. Predicted seed densities and their confidence intervals for each harvest intensity. Vertical long dash lines indicate the mean values of each climatic variable

Figure 3. Predicted seed densities and their confidence intervals for each mean value of the seed-source index for each harvest intensity 


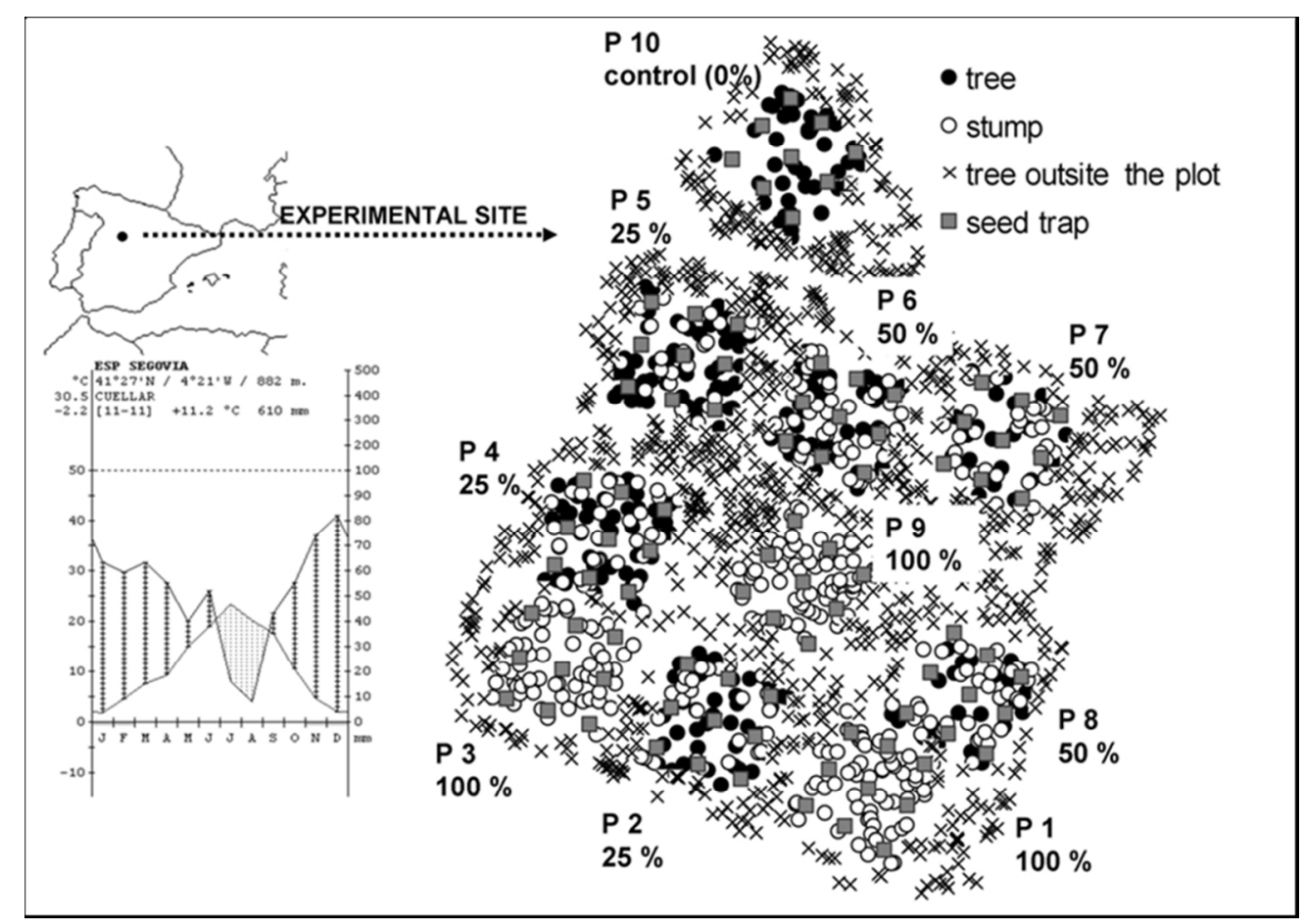

$1674 \times 1184 \mathrm{~mm}(14 \times 14 \mathrm{DPI})$ 


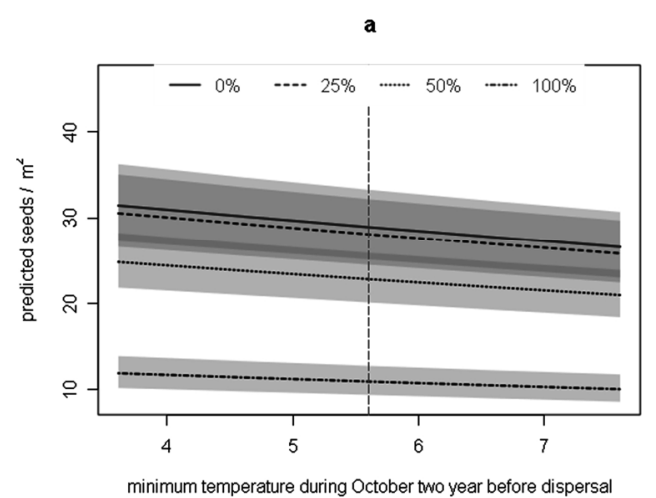

b

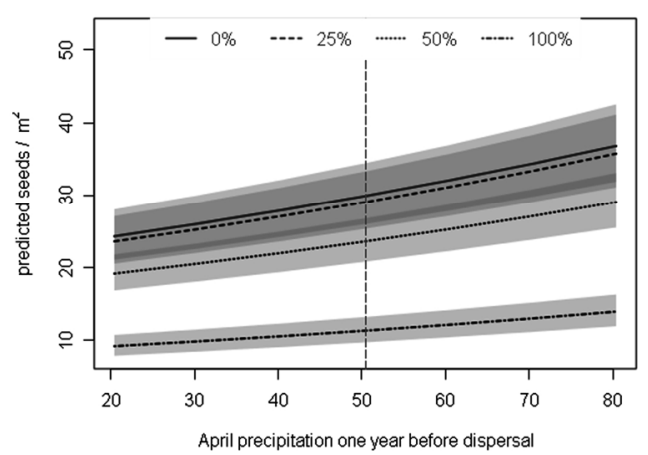

c

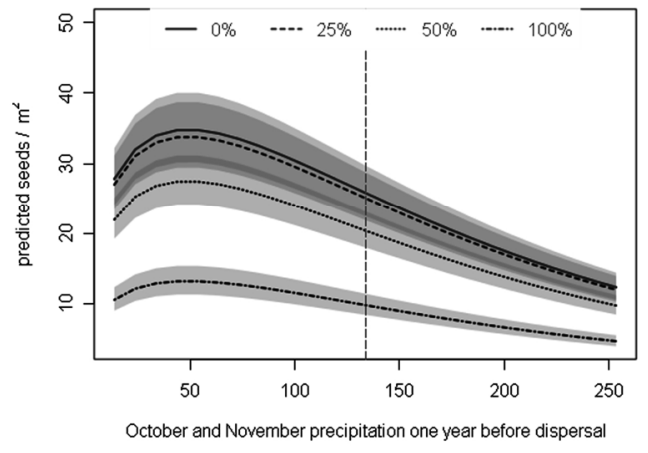

$350 \times 812 \mathrm{~mm}(96 \times 96 \mathrm{DPI})$ 


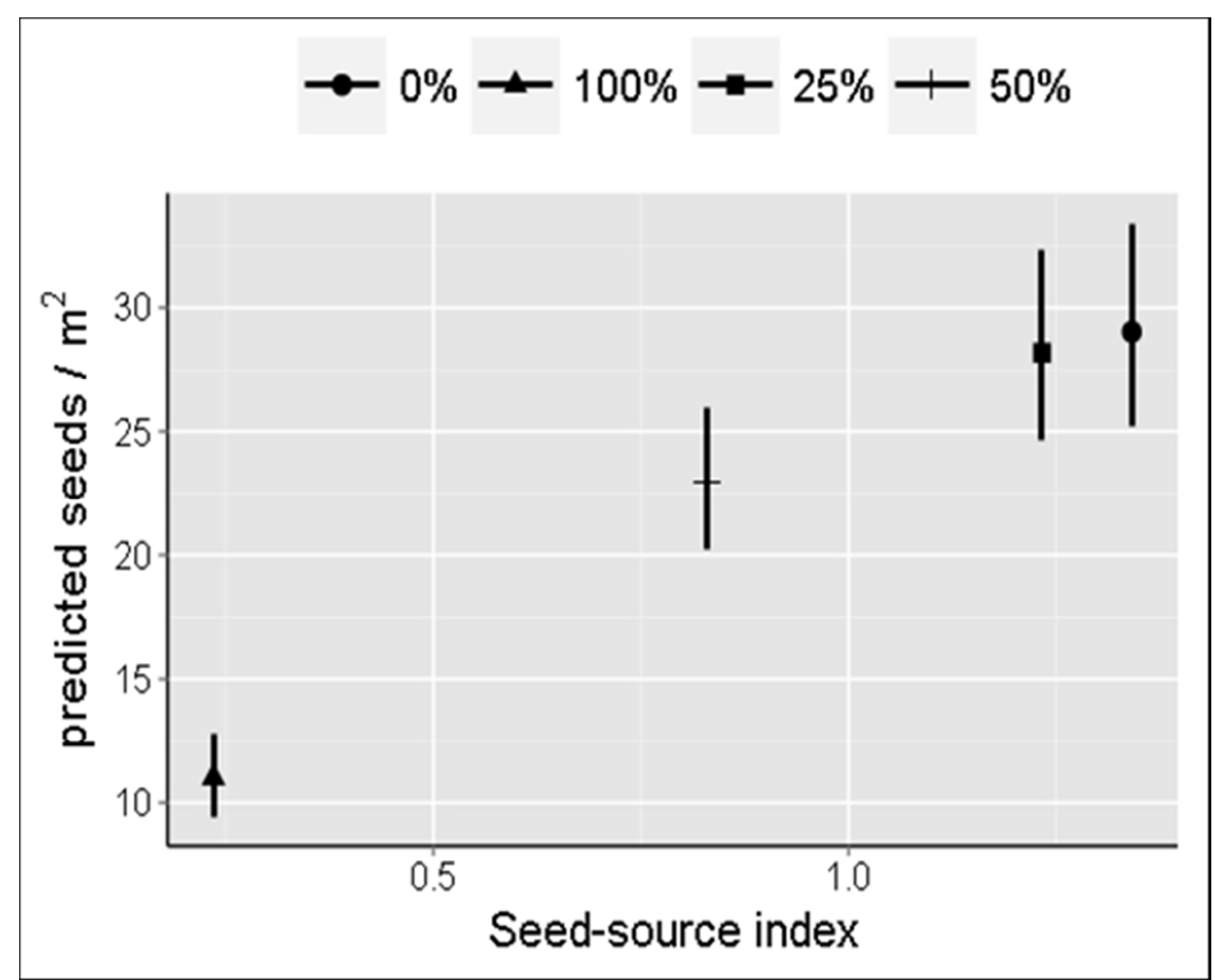

$756 \times 556 \mathrm{~mm}(20 \times 22$ DPI $)$ 